\title{
Review on Production, Husbandry and Sustainability of Free-Ranging Poultry Production Systems in Ethiopia
}

\author{
Teshome Gemechu' 1 , Tesfaye Amene ${ }^{1}$
}

\author{
${ }^{1}$ Department of Animal Science, College of Agriculture and Natural Resources, Mizan-Tepi University, P.O.Box \\ 260, Mizan-Tepi, Ethiopia
}

\begin{abstract}
A review was undertaken to obtain the related research results and facts on production, husbandry and sustainability of free-range poultry production systems in Ethiopia with the aim of delivering synthesized and summarized information to the beneficiaries. Poultry production has a major role in poverty alleviation by means of income generation and household food security. Free-range chicken production is characterized by low input and output scavenging, with minimal investment in housing, feeding, watering and health care, and hence weak biosecurity, high off take rates and high mortality rates. The production system in Ethiopia is extensive and dominated by indigenous chickens that exhibit remarkable adaptation to local environments. Generally, it is concluded that, the free-range chicken production system offers many people the opportunity to improve their livelihoods, suggesting that improvement of chicken breeding, production environment, farmers' access to inputs and markets needs to focus on the free-range chicken production system.
\end{abstract}

Keywords: Free-range Poultry, Husbandry, Production, Sustainability

\begin{abstract}
Introduction
Livestock production in general and chickens in particular play important socioeconomic roles in developing countries (Alders, 2004; Salam, 2005). Poultry production has a major role in the economy of developing countries, including an important role in poverty alleviation by means of income generation and household food security (FAO,1997; Gondwe, 2004 and Abdelqader et al., 2007). Provision of animal protein, generation of extra cash incomes and religious/cultural considerations are amongst the major reasons for keeping village chickens by rural communities (Alders et al., 2009). Nearly all rural and peri urban families in developing countries keep a small flock of free range chickens (Jens et al., 2004).
\end{abstract}

Village chickens are also an integrated component of nearly all rural, many peri-urban and some urban households and accounts for more than $60 \%$ of the total national chicken population in most African countries (Branckaert et al., 1999; Sonaiya, 1990). According to Robert et al. (1992) and Sonaiya (2005) reports; small farming families, landless laborers and people with incomes below the poverty line were able to raise village birds with low inputs and harvested the benefits of eggs and meat via scavenging feed resources. However, most rural communities lack the required husbandry skills, training and opportunity to effectively improve their chicken production (Mlozi et al., 2003).

In Ethiopia chickens are the most widespread and almost every rural family owns chickens, which provide a valuable source of family protein and income (Tadelle et al., 2003). The total chicken population in Ethiopia is estimated at 49.3 million (CSA 2011), with 99\% of the population consisting of indigenous breeds reared under village production systems, and the remaining $1 \%$ being exotic breeds reared under intensive management (Tadelle and Ogle, 2001). However, Ethiopian CSA (2013) reported that $96.9,0.54$ and $2.56 \%$ of the total poultry were reported to be indigenous, hybrid and exotic, respectively. The majority $(99 \%)$ of these chickens are maintained under a traditional system with little or no inputs for housing, feeding or health care. The most dominant chicken types reared in this system are local ecotypes, which show a large variation in body position, color, comb type and

This article is published under the terms of the Creative Commons Attribution License 4.0

Author(s) retain the copyright of this article. Publication rights with Alkhaer Publications.

Published at: http://www.ijsciences.com/pub/issue/2015-04/

Article Number: V420150406; Online ISSN: 2305-3925; Print ISSN: 2410-4477 
productivity (Teketel, 1986; Tadelle et al., 2003b; Halima et al., 2007). The greater part of the feed for village chicken is obtained through scavenging, which includes the household cooking waste, cereal and cereal by-products, pulses, roots and tubers, oilseeds, shrubs, fruits and animal proteins (Samson and Endalew, 2010).

More than half of Ethiopian households both in rural and urban areas keep chickens, although there is considerable variation in the distribution of chicken keeping, with most households in highland areas are keeping chickens, and far fewer doing so in lowland pastoral areas (Ayele et al., 2009 and Wilson, 2010). It is difficult to design and implement chicken-based development programs that benefit rural people without understanding village chicken production systems (Gueye, 1998; Pedersen, 2002). Hellin et al. (2005) also reported that understanding of village chicken functioning and marketing structure are a prerequisite for developing market opportunities for rural households and could be used to inform policy makers and development workers in considering the commercial and institutional environment in which village chicken keepers have to operate.

To improve the productivity of free-ranging poultry production system; having basic knowledge about poultry production husbandry and sustainability are indispensable. However, there is a limitation to reviewing these and other related information and thereby to delivering such synthesized and summarized data to the beneficiaries.

Therefore, reviewing sensible findings on production, husbandry and sustainability of free-ranging poultry production system seems to be a milestone area to deliver combined information to the beneficiaries. Based on this outlined background, the objective of this paper was:

- Review on production, husbandry and sustainability of free-ranging poultry production system and thereby to deliver combined information for beneficiaries.

Most of the related research findings of production, husbandry and sustainability of free-ranging poultry production system were reviewed. Related reports which focus on housing, flock size, village chicken production, management, feeding and watering practices were also reviewed. Findings on poultry production that have been reported by various scholars were also reviewed and combined.

\section{Description of Free-range Poultry production Systems}

The poultry sector in Ethiopia can be characterized into three major production systems, namely the large-scale commercial, the small scale commercial and the village or backyard poultry production system. Each can sustainably coexist and contribute to solve the socio-economic problems of different target societies (Tadelle et al., 2003a). The backyard poultry production system is characterized by low input, low output and periodic destruction of large proportion of the flock due to disease outbreaks (Tadelle et al., 2003b).

Free-range chicken production systems are the techniques under which the birds are unrestricted in their movements except that they are usually shut up at night for protection from predators. Local chicken production is predominantly based on scavenging, a low input and low output production system. Scavenging made up $82.9 \%$ of the production system using a majority $(96.8 \%)$ of local chicken ecotypes, with only seasonal/conditional feed supplementation. Safalaoh (2001) and Lwesya et al. (2004) reported that almost $83 \%$ of the total chicken population in Malawi smallholder extensive chicken production system was indigenous chicken eco-types, forming the largest proportion of birds kept. Huque and Paul (2001) also reported that chicken production systems of Bangladesh depend mainly on locally scavenging chickens that were reared in villages and they constituted more than $70 \%$ of the country's chicken population.

Free-range chicken production is characterized by low input and output scavenging, with minimal investment in housing, feeding and health care, and hence weak biosecurity, high off take rates and high mortality rates. The system is only partially marketoriented, production being targeted for both household consumption and the open market (Gezahegn and Karl, 2010). The system generally does not involve investments beyond the cost of the foundation stock (USAID, 2010). The majority of village chickens are kept during available feed resource and when the risk of predators is low. Different authors (Mengesha, 2012; Dessie et al., 2013) that there were no cultural/religious taboos against consumption and marketing of chicken and eggs in Ethiopia.

\section{Free-range Poultry Husbandry}

\section{Housing system of free-range chicken}

Chicken houses constructed from locally available materials, with well built wall, adequately ventilated with corrugated wire, equipped with watering and feeding materials and provided with litter material was considered as constructed based on the recommended government extension package for poultry housing. The lesser use of recommended specifications in poultry house construction indicates the lack of technical training on scientific poultry rearing to the producers. Generally, it was also 
observed that few households residing near the town and main road to Addis Ababa provided electricity and litter material in poultry houses. Moges et al. (2010) and Takele and Ali (2011) reported that, the provision of electricity and litter material for village chicken was not practices in most parts of Ethiopia. Bothe fixed and mobile shedding are common used in free-range systems. The fixed sheds have litter, perches and nest boxes. However, fixed housing is rarely used in free-range operations, with the most popular system being the use of movable shelters and birds provided an area of pasture in a rotational system (Glatz and Yingjun, 2004).

According to Desalew et al. (2013) finding, from the total of 280 chicken owners interviewed, only 62 farmers $(22.1 \%)$ prepared separate overnight houses for village birds. Majority (77.9\%) of village chicken owners kept birds on various night sheltering places including; perches inside the house $(45.7 \%)$ on the floor covered by bamboo made materials $(27.1 \%)$, on ceilings of the house $(3.6 \%)$ and under locally constructed sitting place $(1.4 \%)$. On the other hand, Mandal et al. (2006) reported that $97.5 \%$ households construct separate house in India for chickens as night enclosure. Muchadeyi et al. (2004) also reported that $82 \%$ of the households in Zimbabwe provided separate housing for their chicken, while the remaining $18 \%$ had no separate chicken housing.

\section{Feeding and watering practices of free-range chicken}

The dominant system of poultry feeding practiced in Ethiopia is free scavenging with supplementary feeding. However, the proportion of those that supplement their chicks with a commercial ration is very small (Halima, 2007; Moges et al., 2010 and Mengesha et al., 2011).

Supplementary feed was provided by majority $(97.5 \%)$ of chicken owners, while $84.3 \%$ of them did this between the months of July to September. Grains and household leftovers were the major kinds of feeds stuffs $(56.4 \%)$ supplemented by chicken owner farmers. Most these chicken owners $(87.1 \%)$ used cereal crop harvest (self produced grains) as supplementary feed (Fisseha et al., 2010). Halima (2007) also reported that $99.3 \%$ of chicken owners in North West Amhara Region provided supplementary feeds to village birds. Similarly, Mapiye et al. (2005) reported that $95.5 \%$ of the farmers in Rushinga district of Zimbabwe produced their own supplementary feeds and only $4.5 \%$ used purchased feed.

Desalew et al. (2013) revealed that, about $96 \%$ of respondents were provided water with free access. Likewise, Moges et al. (2010) and Mengesha et al. (2011) reported similar, watering practices in Bure district of North West Zone of Amahra region and Jamma district of South Wollo, respectively. All village chicken owners $(100 \%)$ of the district provided water to village chickens; $85.4 \%$ only during the dry season and $14.3 \%$ throughout the year. The major sources of water for chicken in the area were river $(30.4 \%)$, spring $(28.5 \%)$, locally made underground water $(21.4 \%)$ and pipe water $(19.7 \%)$. Majority of chicken owners $(98.2 \%)$ had watering trough. Broken clay material, locally called "shekila", $(37.3 \%)$, wooden trough $(32.7 \%)$ and plastic made trough $(28.2 \%)$ were the most widely used types of watering troughs (Desalew et al., 2013).

\section{Chicken health and disease control measures}

Melesse and Negesse (2009) reported that disease was cited as the most important constraint of village chicken production in southern parts of Ethiopia. Newcastle disease (NCD) was the most (98.2\%) prevalent and economically important disease problem affecting free-range birds and it is reported to be the first major causes of chicken death/loss (Fisseha et al., 2010). Similarly, Halima (2007) reported that the major causes of death for local birds in North West Amhara were seasonal outbreaks of diseases, specifically Newcastle disease. The prevalence of the NCD and mortality of chicken were higher at the start of rainy season, mainly on April $(66.8 \%)$ and May (31.4\%). Serkalem et al. (2005) also reported that $\mathrm{NCD}$ was one of the major infectious diseases affecting productivity and survival of village chickens in central highlands of Ethiopia. Similarly, Kusina et al. (2000) reported that NCD was identified and accepted as the greatest danger to the expansion of chicken production in Zimbabwe.

Free-range chicken owners had no any culture of vaccinating birds against diseases in Ethiopia. This might be due to lack of awareness about the presence of chicken vaccines, lack of attention to free-range chickens and low availability of vaccines. A traditional treatment was the major type of treatment used by majority of free-range chicken owners (95\%) against NCD. Accordingly provision of a mixture of local alcohol ('Arekie'), lemon and onion to sick birds against NCD was the most widely used type of traditional treatment. Other common types of traditional treatments observed were; use some herbs like 'semiza' (Justitia schemperina) and 'endod' (Phytolacca dodecandra) (33.2\%) and use of tetracycline capsule (Fisseha et al., 2010).

\section{Role of family in free-range chicken production system}

All family members provided labor for chicken husbandry practices. Men were responsible for few activities like construction of shelter and taking sick birds for treatment. However, women were highly responsible for many activities like cleaning bird's 
house, feeding birds, selling birds and eggs. Children also participated in various husbandry activities like cleaning of bird's house, provision of supplementary feed and water (Fisseha et al., 2010).

Similarly, Bradley (1992) declared that management of village chicken had been highly associated with women for various historical and social factors. Riise et al. (2004) and Kitalyi (1998) also reported that women and children were generally in charge of village chicken husbandry practices in developing countries. Abubakar et al. (2007) also reported that women and children involvement was by far the highest on village flocks management labor profile activities included; sheltering birds, cleaning bird's house, feeding and watering of birds in some parts of Nigeria and Cameroon. Mapiye et al. (2005) also reported that women in Zimbabwe were dominated in most village chicken production activities like; feeding $(37.7 \%)$, watering $(51.2 \%)$ and cleaning of bird's house $(37.2 \%)$ whereas men were dominant in shelter constructions $(60 \%)$ and treatment of birds $(40 \%)$.

\section{Flock size and Structures}

Chicken production has occurred largely on small farmer holdings, with an average flock size of 4.1 (CSA, 2005), limited capital investment and few inputs provides an overview of chicken production in Ethiopia (FAO, 2004; Alemu et al., 2008 and Wilson, 2010). The average flock size per household for hens, cocks, pullets, cockerels and young chicks was 3.3, 1, 2.3, 0.9 and 5.6, respectively; with a total flock size of 13 birds and a hen to cock ratio of $3.7: 1$. The average flock size per household varied between seasons mainly due to feed availability, the occurrence of diseases and predators (Fisseha et al., 2010). Likewise, the chicks, hens and pullets (80\%) dominated the flock structure and were mainly retained for production purposes in Western Kenya (Ochieng et al., 2013). On average households kept 23 chickens, two times higher than the reported average in Western Kenya (Njue et al., 2006). Reduction of flock sizes may be the attribution of the limited availability of scavenging feed sources in Ethiopia. Currently, shortage of scavenging feed source is aggravated by reduced land sizes of the backyards, deforestation of the homesteads and lack of decomposition materials from the vicinity of the backyards in the country.

\section{Strategy of sustainable free-range chicken production systems}

Smallholder free-range chicken production is the major source of chicken supply. Large-scale commercial chicken production is insignificant, accounting for only $1 \%$ the national chicken production (Tadelle et al., 2002). The free-range chicken production system offers many people the opportunity to improve their livelihoods, suggesting that improvement of chicken breeding needs to focus on the free-range chicken system. The genetic improvement strategy adopted to improve chicken productivity and production in Ethiopia focuses mainly on importation and dissemination of exotic breeds and crossbreeding. Utilization of the exotic resources needs to be rationalized so that distribution of exotic chickens is limited to commercial farms and villages with adequate access to production inputs, such as compound feeds, and close to markets that are generally located around urban areas (Dessie et al., 2013).

Collaborations with internationally operating poultry breeding companies are also required. Recurrent selection within the indigenous populations could facilitate conservation of the adapted indigenous genetic resources, which are at risk from the indiscriminate dissemination of the exotic breeds into villages. Improvement of the genetic merits of indigenous chicken ecotypes through breeding has been absent until recently when a nucleus-breeding program for Horro chicken was set up at Debre Zeit Research Centre (Dana, 2011). Recurrent selection breeding schemes suited to smallholder village conditions are usually difficult to design. One approach could be to disseminate improved cocks from the nucleus flock at Debre Zeit to villagers' organized in a cooperative breeding program. Improved birds in the nucleus flock could also be used alternatively in crossbreeding where they are crossed with exotic sires to produce crossbred hens and cocks to be distributed to villages.

Based on experiences from cooperative village-based sheep-breeding programs in Ethiopia, village breeding schemes for chickens could be designed. Breeding schemes suited to village conditions involving simple exchange of breeding roosters among cooperating villagers to more complex selection schemes involving pedigree records and performance evaluation need to be assessed for their feasibility and efficiency to bring about genetic improvement in local breeds (Gizaw et al., 2011).

Genetic improvement programs need to be coupled with improvement of the production environment. Feed shortages and diseases are mentioned by the surveyed farmers as major problems. Compound commercial feeds are currently very costly. Research on low-cost poultry rations based on farm produce is urgently required. Diseases, particularly New Castle Disease, remain to be a major problem for village chicken production, though preventive measures are now available. Controls for this persistent disease problem need to be addressed (Dessie et al., 2013). 


\section{CONCLUSION AND RECOMMENDATIONS}

Poultry production in Ethiopia can be characterized into three major production systems, namely the large-scale commercial, the small scale commercial and the village or free-range poultry production system. Free-range chickens are predominantly produced under a scavenging, low input-output system and primarily used as the source of income and empowerment to the rural women and children. Chicken houses constructed from locally available materials and the dominant system of chicken feeding practiced in Ethiopia is free scavenging with supplementary feeding. Free-range chicken owners had no any culture of vaccinating birds against diseases in Ethiopia. This might be due to lack of awareness about the presence of chicken vaccines, lack of attention to free-range chickens and low availability of vaccines. All family members provided labor for chicken husbandry practices. Men were responsible for few activities like construction of shelter and taking sick birds for treatment. However, women were highly responsible for many activities like cleaning bird's house, feeding birds, selling birds and eggs. Currently, shortage of scavenging feed source is aggravated by reduced land sizes of the backyards, deforestation of the homesteads and lack of decomposition materials from the vicinity of the backyards in the country. Therefore, the following recommendations are suggested for the sustainability of free-range production system based on the result of the current review:

$>$ Technical interventions in free-range chicken production would include control of disease, improved feeding and watering, housing and introduction of market-oriented improved breeding practices to improve the genetic merits of the indigenous genetic resources through recurrent selection within the indigenous population and crossbreeding with exotic breeds.

$>$ Provision of credit facilities to chicken owners for the enhancement of inputs, access to more profitable markets and training of farmers are the major interventions for enhancing the contribution of free-range chicken production to farmers' livelihoods.

$>$ As most of free-range chicken production activity is managed by women and children, provision of successive trainings on modern chicken husbandry practices to women would be essential for the improvement of chicken production and productivity.

\section{REFERENCES}

I. Abdelqader, A., Wollny, C. B. A. and Gauly, M., 2007. Characterization of local chicken production systems and their potential under different levels of management practice in Jordan, Tropical Animal
Health and Production, 39, 155-164 http://dx.doi.org/10.1007/s11250-007-9000-x

II. Abubakar, M.B, A.G. Ambali and T. Tamjdo.2007. Rural Chicken Production: Effects of Gender on Ownership, and Management Responsibilities in Some Parts of Nigeria and Cameroon. International Journal of $\begin{array}{llll}\text { Poultry Science } 6 & \text { (6): } & 413-416\end{array}$ http://dx.doi.org/10.3923/ijps.2007.413.416

III. Alders R.2004. Poultry for profit and pleasure. FAO Diversification Booklet 3. Rome.

IV. Alders RG, Pym RAE. 2009. Village poultry: still important to millions, eight thousand years after domestication. World's Poult. Sci. J., 65:181. http://dx.doi.org/10.1017/s0043933909000117

V. Alemu, D. Alemu, T. Degefe, S. Ferede, S Nzietcheung, D. Roy, 2008. Overview and Background Paper on Ethiopia's Poultry Sector: Relevance for HPAI Research in Ethiopia. DFID Pro-poor HPAI Risk Reduction Strategies Project Africa/Indonesia Region Report No. 1

VI. Ayele, G. Ayele, D. Asare-Marfo, E. Birol, D. Roy. 2009. Investigating the Role of Poultry in Livelihoods and the Impact of HPAI in Ethiopia. Controlling Avian Flu and Protecting People's Livelihoods in Africa and Indonesia. International Food Policy Research Institute (IFPRI) with the International Livestock Research Institute (ILRI) and Royal Veterinary College (RVC)

VII. Bradley FA.1992. A historical review of women's contributions to poultry production and the implications for poultry development process. In: Proceedings of the $1^{\text {th }}$ World's Poultry Congress, Amsterdam, the Netherlands. pp. 693-696.

VIII. Branckaert, R.D.S. and Guéye. 1999. FAO's Programme for Support to family poultry production. In: Proceedings workshop on poultry as a tool in poverty eradication and promotion of gender equality held March 22 to 26, 1999. Denmark.

IX. CSA (Central Statistical Agency). 2005. Agricultural Sample Survey 2004/05. Central Statistical Authority No. 2. Report on Livestock and livestock characteristics. Stat. Bull. P. 331.

X. CSA (Central Statistical Agency). 2011 Agricultural sample survey 2010/11, 2: statistical bulletin 505 . Report on livestock and livestock characteristics (prevent peasant holdings), Addis Ababa, February 2011.21.

XI. CSA (Central Statistical Agency). 2013. Agricultural sample survey 2012/13. Report on livestock and livestock characteristics, Statistical Bulletin Addis Ababa, Ethiopia. 2:570.

XII. Dana, N. 2011. Breeding programs for indigenous chicken of Ethiopia. PhD thesis. Wageningen, the Netherlands: Wageningen University.

XIII. Desalew Tadesse, Harpal Singh, Ashenafi Mengistu, Wondimeneh Esatu and Tadelle Dessie. 2013. Study on management practices and marketing systems of village chicken in East Shewa, Ethiopia

XIV. Dessie, T., Esatu, W., Waaij, L.V., Zegeye, F., gizaw, S., Mwai, O. and van Arendonk, J. 2013. Village chicken production in the central and western highlands of Ethiopia: characteristics and strategies for improvement. Nairobi, Kenya: International livestock Research institute.

XV. FAO (Food and Agriculture Organization of the United Nations). 2004. Egg marketing. A guide for the production and sale of eggs. FAO, Rome, Italy.

XVI. FAO (Food and Agriculture Organization of the United State Nations). 1997. Guidelines for the inclusion of improved household poultry production. Diversification component of the special programme for food security, Rome. pp: 86.

XVII. Fisseha Moges, Abera Mellesse and Tadelle Dessie. 2010. Assessment of village chicken production system 
and evaluation of the productive and reproductive performance of local chicken ecotype in Bure district, North West Ethiopia. African Journal of Agricultural Research Vol. 5(13), pp. 1739-1748

XVIII. Gezahegn, A. and Rich, K.M. 2010. Poultry value chains and HPAI in Ethiopia. Africa/Indonesia Team Working Paper 25. Washington, DC, USA: International Food Policy Research Institute (IFPRI).

XIX. Gizaw, S., Awigchew, K. and Yami, A. 2011. A practical guide for village-based sheep and goat cooperative breeding scheme. ESGPIP Technical Bulletin 42. Addis Ababa, Ethiopia: ESGPIP.

XX. Glatz Phil and Yingjun. 2004. Developing free-range animal production systems. A report for the Australian Government Rural Industries Research and Development Corporation. Pp 4-23

XXI. Gondwe, T.N.P., 2004. Characterization of local chicken in low input-low output production systems: is there scope for appropriate production and breeding strategies in Malawi? PhD Thesis. Georg-AugustUniversität Göttingen, Germany.

XXII. Gueye, E.F. 1998. Village egg and fowl meat production in Africa, World's Poultry Science Journal, 54, 73-86 http://dx.doi.org/10.1079/wps19980007

XXIII. Halima H.2007. Phenotypic and Genetic Characterization of Indigenous Chicken Populations in Northwest Ethiopia. PhD Thesis; University of the Free State, Bloemfontein, South Africa. P. 186.

XXIV. Hellin J, Griffith A, Mike A. 2005. Mapping the market: Market-literacy for agricultural research \& policy to tackle rural poverty in Africa. In: Proceedings of an International Seminar, 28 $8^{\text {th }}$ February $1^{\text {st }}$ March 2005, Westminster, London, UK, pp. 110-150.

XXV. http://www.lrrd.org/lrrd16/6/much16040.htm

XXVI. Huque QME, Paul DC. 2001. Strategies for family poultry production with special reference to women participation. Paper presented in $1^{\text {st }}$ SAARC Poultry Conference held on 24-26, September. Pune, India.www.cipav.org.co/lrrd/lrrd9/3/bang931.htm.

XXVII. Jens Christian R, Anders P, Charlotte V, Ainsh MC, Lone F. 2004. Keeping Village Poultry. A technical manual for small-scale poultry production. Copenhagen, Denmark.

XXVIII. Kitalyi A.1998. Village chicken production systems in rural Africa. Households food and gender issues. Food and Agriculture Organization of the United Nations: Rome Italy. P.81

XXIX. Kusina J, Kusina NT, Mhlanga J. 2000. A Survey on Village Chicken Losses: Causes and Solutions as perceived by farmers in communal area of Zimbabwe. Accessed on $27^{\text {th }}$ August, 2007.

XXX. Lwesya H, Phoya RKD, Safalaoh ACL, Gondwe TNP. 2004. Rearing chicks in enclosures under village conditions: effect on growth and reproductive performance of hens. Livestock Res. Rural Dev., 16: 11 .

XXXI. Mandal MK, Khandekar N, Khandekar P. 2006. Backyard poultry farming in Bareilly district of Uttar Pradesh, India: an analysis. Livest. Res. Rural Dev., 18. Art. \# 7. http://www.lrrd.org//rrd18/7/mand18101.htm

XXXII. Mapiye, C. and S. Sibanda. 2005. Constraints and opportunities of village chicken production systems in the smallholder sector of Rushinga District of Zimbabwe. Livestock Res. Rural Dev. 17 (10). http://www.cipav.org.co/lrrd/lrrd17/10/mapi17115.htm. Acessed: 04/11/2005.

XXXIII. Melesse A, Negesse T. 2009. Study on the characterization of local chickens found in Southern Ethiopia. In: Proceedings of Annual Research Review Workshop, Hawassa University, Awassa, Ethiopia, May 16-17. Pp.1-15.

XXXIV. Mengesha M, Tamir B, Dessie T. 2011. Village Chicken Constraints and Traditional Management Practices in Jamma District, South Wollo, Ethiopia.
Livestock Research for Rural Development. Volume 23, Article \#37. Retrieved February 5, 2013, from http://www.lrrd.org/lrrd23/2/meng23037.htm.

XXXV. Mengesha M, Tamir B, Dessie T. 2012. Village Chicken Constraints and Traditional Management Practices in Jamma District, South Wollo, Ethiopia. Livestock Research for Rural Development. Volume 23, Article \#37. Retrieved February 5, 2013, from http://www.lrrd.org/lrrd23/2/meng23037.htm

XXXVI. Mlozi MRS, Kakengi AVM, Minga UM, Mtambo AM, Olsen JE. 2003. Marketing of free range local chicken in Morogoro and Kilosa urban markets, Tanzania. Livestock Res. Rural Dev., 15:2.

XXXVII. Moges F, Abera M, Tadelle D. 2010. Assessment of village chicken production system and evaluation of the productive and reproductive performance of local chicken ecotype in Bure district, North West Ethiopia. Afr. J. Agric. Res. 5(13):1739-1748.

XXXVIII. Muchadeyi FC, Sibanda S, Kusina NT, Kusina J, Makuza S. 2004. The village chicken production system in Rushinga District of Zimbabwe. Livest. Res. Rural Dev., 16. Art. \# 6.

XXXIX. Njue, S. W., Kasiiti, J. L. \& Gacheru, S. G.2006 Assessing the economic impact of commercial poultryfeeds supplementation and vaccination against Newcastle disease in local Chicken in Kenya. Proceedings of afinal research coordination meeting organized by the Joint FAO/ International Atomic Energy Agency (IAEA) held in Vienna, 24-28 May 2004.

XL. Ochieng Justus, George Owuor, Bockline Omedo Bebe. 2013. Management practices and challenges in smallholder indigenous chicken production in Western Kenya. Journal of Agriculture and Rural Development in the Tropics and Subtropics Vol. 114 No. 1 (2013) $51-58$

XLI. Pedersen CV.2002. Production of semi-scavenging chickens in Zimbabwe. Ph.D Thesis. Royal Veterinary and Agricultural University, Copenhagen, Denmark.

XLII. Riise JC, Permin A, Kryger KN.2004. Strategies for developing family poultry production at village level. Experiences from West Africa and Asia. Network for Smallholder Poultry Development, Dyrlaegevej Frederiksberg, Denmark. 2:1870. http://dx.doi.org/10.1079/wps200437

XLIII. Robert JA. 1992 The scavenging feed resource base in assessment of the productivity of scavenging chickens. Newcastle disease in village chickens, control with thermo stable vaccine. In: Proceedings of ACIAR, No. 39, Canberra, Australia. pp. 29-32.

XLIV. Safalaoh ACL. 2001. Village Chicken Upgrading Programme in Malawi.World's Poult. Sci. J., 57: 179-188. http://dx.doi.org/10.1079/wps20010013

XLV. Salam KR. 2005. Improvement of village chicken production in a mixed (chicken-ram) farming system in Burkina Faso. Ph.D Thesis. Wageningen Institute of Animal Sciences, Animal Nutrition Group, Wageningen University, the Netherlands.

XLVI. Samson L, Endalew B. 2010. Survey on Village Based Chicken Production and Utilization System in Mid Rift Valley of Oromia, Ethiopia. Global Vet., 5 (4): 198203.

XLVII. Serkalem T, Hagos A, Zeleke A. 2005. Sero-prevalence study of Newcastle disease in local chickens in central Ethiopia. Inter. J. Appl.Res. Vet. Med., 3:1.

XLVIII. Sonaiya EB, Swan SEJ. 2005. Small-scale poultry production, technical guide manual. FAO Animal Production and Health 1. Food and Agriculture Organization of the United Nations (FAO), Rome.

XLIX. Sonaiya, E.B. 1990. Toward sustainable poultry production in Africa. In: Paper presented at the FAO expert consultation on strategies for sustainable animal agriculture in developing countries, Rome, Italy. 
L. Tadelle D, Million T, Alemu Y, Peters K. 2003. Village chicken production systems in Ethiopia: Use patterns and performance valuation and chicken products and socio-economic functions of chicken.

LI. Tadelle D, Million T, Alemu Y, Peters KJ. 2003b. Village chicken production systems in Ethiopia: 2. Use patterns and performance valuation and chicken products and socio-economic functions of chicken; Livestock Research for Rural Development (15) 1. Retrieved February 5, 2013, from http://www.lrrd.org/lrrd15/1/tadeb151.htm.

LII. Tadelle D, Million T, Alemu Y, Peters KJ. 2003a. Village chicken production systems in Ethiopia: 1. Flock characteristics and performance; Livestock Research for Rural Development (15) 1.Retrieved February 5, 2013, fromhttp://www.lrrd.org/lrrd15/1/tadea151.htm.

LIII. Tadelle D. 2002. Phenotypic and genetic characterization of chicken ecotypes in Ethiopia. $\mathrm{PhD}$ thesis. Humboldt University, Germany. 208 pp.

LIV. Tadelle Dessie, Ogle B. 2001. Village poultry production system in the Central Highlands of Ethiopia. Trop. Anim. Health Prod. 33:521-537. http://dx.doi.org/10.1023/a:1012740832558

LV. Takele T, Oli W. 2011. Uses and flock management practices of scavenging chickens in $\mathrm{W}$ olaita Zone of southern Ethiopia. Trop. Anim. Health Prod. 44:537-544. http://dx.doi.org/10.1007/s11250-0119933-y

LVI. Teketel Forsido. 1986. Studies on the meat production potential of some local strains of chicken in Ethiopia. Ph.D Thesis. J.L.University of Giessen, Germany. 210 p.

LVII. USAID (United States Agency for International Development). 2010. Partnership for safe poultry in Kenya (PSPK) program: Value chain analysis of poultry in Ethiopia. Addis Ababa, Ethiopia: USAID.

LVIII. Wilson RT. 2010. Poultry production and performance in the Federal Democratic Republic of Ethiopia. World's Poult. Sci. J. 66:441-454. http://dx.doi.org/10.1017/s0043933910000528 